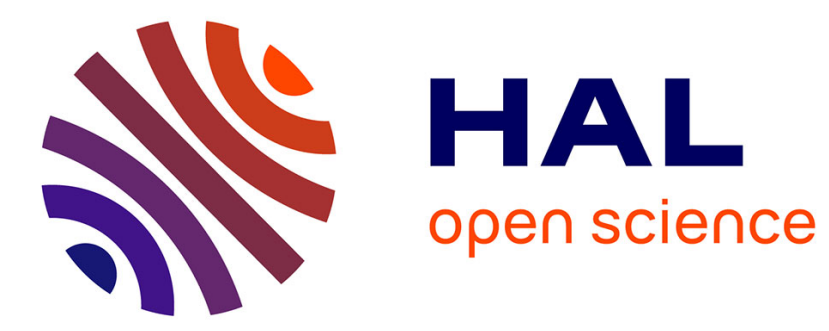

\title{
EXPLOSIVE FACILITIES FOR MECHANICAL TESTING OF MATERIALS AND CONSTRUCTIONS
}

\author{
S. Nowikow, V. Petrov, L. Timonin
}

\section{To cite this version:}

S. Nowikow, V. Petrov, L. Timonin. EXPLOSIVE FACILITIES FOR MECHANICAL TESTING OF MATERIALS AND CONSTRUCTIONS. Journal de Physique IV Proceedings, 1991, 01 (C3), pp.C3-441-C3-446. 10.1051/jp4:1991362 . jpa-00250506

\section{HAL Id: jpa-00250506 https://hal.science/jpa-00250506}

Submitted on 1 Jan 1991

HAL is a multi-disciplinary open access archive for the deposit and dissemination of scientific research documents, whether they are published or not. The documents may come from teaching and research institutions in France or abroad, or from public or private research centers.
L'archive ouverte pluridisciplinaire HAL, est destinée au dépôt et à la diffusion de documents scientifiques de niveau recherche, publiés ou non, émanant des établissements d'enseignement et de recherche français ou étrangers, des laboratoires publics ou privés. 
Colloque C3, suppl. au Journal de Physique III, Vol. 1, octobre 1991

\title{
EXPLOSIVE FACILITIES FOR MECHANICAL TESTING OF MATERIALS AND CONSTRUCTIONS
}

S.A. NOWIKOW, V.A. PETROV and L.M. TIMONIN

VNIIEF 607200 Arzamas, Nizhnii Nowgorod, USSR

\begin{abstract}
RESUME : Une brève description est faite sur quelques dispositifs expérimentaux par explosifs qui sont destinés aux essais de résistance dynamique des déformations $10^{-2}$ $10^{3}$. $\mathrm{S}^{-1}$. Divers états de contraintes de chargement mécanique des structures de dimentions différentes sont décrits dans cet article en fonction des parametres de chargement impulsionnels.
\end{abstract}

Abstract - A brief description of some existing experimental explosive devices for material dynamic strength tests at strain rates of $10^{2}-10^{3} \mathrm{~s}^{-1}$ and different stressed states and for mechanical loading of structures, of different overall dimensions, with loading pulse parameters, varying in a wide range are considered in this report.

\section{1.- Methods of pressure pulse formation of the specified shape.}

The main problems in the development of explosive devices are:

1 - pressure pulse extention (pressure reduction at the wave front, increase of pulse duration),

2 - localization of explosion effect that is significant for stationary devices in laboratory conditions.

Method of pressure pulse "extention" by means of crashers (dumpers), applied in inpact tests, is successfully used in inpact loading [1]. To achieve impact impulse of a trapezoidal shape, the dynamic diagram of dumper compression must correspond to perfectly plastic body. Some porous materials and tubular crashers have the dyagram of nearly the same shape $\{2,3,4]$. Pressure pulse, corresponding to trapezoidal (or rectangular) is shaped, when dumper is compressed within the constant pressure region.

Test stands of the type are best suited, as they are simple in fabri- 
dation. however increasing pulse duration a substantial increase in HE charge mass is needed, that is not always possible. These difficulties can be avolded when the whole system loading device and test sampioj is mounted in a barrei with one end being ciosed. Such device is doscribed in the work [5]. When it charge is detonated, the initial pressure peak is "cut" by damper, while shock wave being spread through it. and acceleration of the moving system is realised mainiy due to explosion products (EP) residudi pressure effect on the striker. This provides similar ioading regimes of a test sampie with the explosive charge mass being lesser than in the first method of loading nere described, and which is approximately half as the damper deformation.

The residuai EP pressure, used for impact impuise generation, made it possible to carry out comparatively easy the tests of structures on the effect of the mechanicai puises with decreasing in time ioad.

Test stand consist of an explosion chamber shock-wave attenuator made in the form of a plug with throtting siots, accelerating section, prossure reisse and deceiorating sections.

Experimental-calculation technique, based on the experimental load versus $t$ ime dependences and on fitting of the corresponding analytic depender.us and integration of the test sample equation of motion has been deveioped for calculation of the loading impulse parameters [6]. bisrepancy between calculated values and experimental ones is not. more than $10 \%$.

\section{2.- Devices for dynamic testing of structural materials.}

The spit-Hopkinson-bar method (SHB), is used in dynamic tests of materials at uniaxial compression and tension in the strain rate range $\dot{\varepsilon}=10^{2} \ldots 10^{4} \mathrm{~s}^{-1}$. For the first time this method, used in explosive loading was applied in work [7]. According to this method, used in compression tests, a sample in the form of short cyinder is placed between the ends of two measuring bars (transmitting and supporting) and is exposed to a stress wave, generated in transmitting bar by means of the mentioned loeding device lexplosive loading by the damperi. The sample, used in tension tests, had a form of a cap and the supporting bar had a tubular form. Similar experimental procedure is used in materials crack resistance tests [8], where specific wedge sampies are used, the end $c r^{\prime}$ the loading bar has a wadge form. The dingram of experimentai configuration, used in these tests, are shown in Figs. $1 a, b, c$. Where $1 \ldots 4$ are the elements of the loading device,5,9- 
$a$

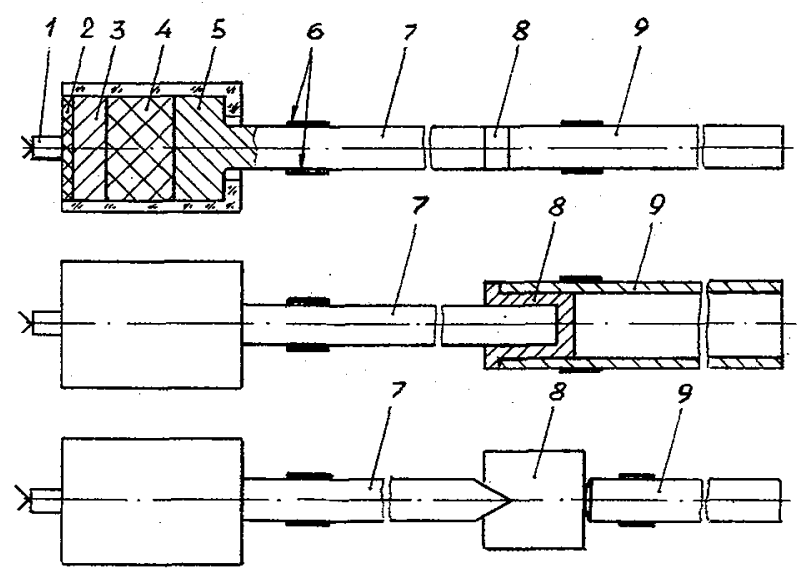

Fig.1

are tranmitting and supporting bars, 8 -is the sample, 6 -are tensometers. Some experimental test results are given in work [9].

The scheme of a device for dynamic compression tests, disposed in ciose proximity to reactor active zone, is given in Fig.2.Localization of the explosion effect is provided by a steel chamber 1 . The results of practical application of such devices are considered in work [10]. Besides, a series of devices for dynamic nateriale in combined stress test has ben developed, constructions of these devices and investigati in resuits are reported in works $[11,12]$.

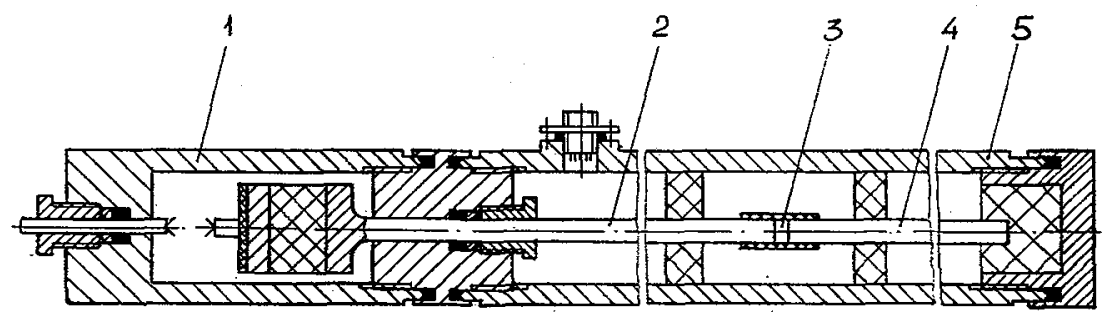

Fig.2

\section{3.- Compact impact test stands for mechanical overload tests of structure components.}

Two constructions of compact impact test stands for testing structure components subjected to comparatively small overloads to $10^{3}$ units, trapezoidal pressure puiseduration of $5 \cdot 10^{3}$ s, the test samle velosity 
drop up to $50 \mathrm{~m} / \mathrm{s}$, are reported in work [12].

Impact test stand of the most simple construction is shown in Fig. 3.

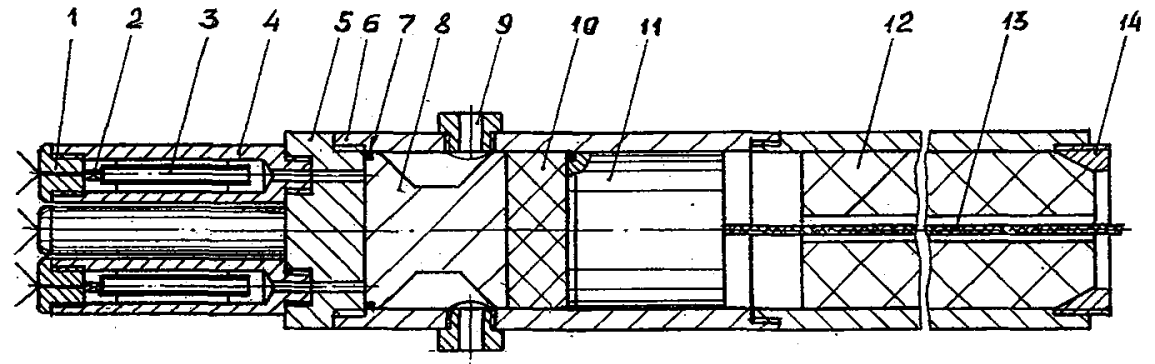

Fig. 3

The test stand has a stell casing in the form of a barrel 6 with $140 \mathrm{~mm}$ inner diameter and $25 \mathrm{~mm}$ wall thickness. The barrel length may be varied. At one end of the barrel there is a throttling plug-shock waves attenuator. The test stand is provided with four explosion chambers 4 of $30 \times 13$ steel with $70 \mathrm{~mm}$ outer diameter, $18 \mathrm{~mm}$ wall thickness and $500 \mathrm{~mm}$ length. Explosive charge in the form of a tube is made of steel-TEN-based explosive. A piston-striker 8, a loading dumper 10 and a test sample 11 are mounted inside the barrel. To reduce gas leakage the piston is provided with a self-sealing gasket $\%$. As the piston-striker passed through the throttling slots 9 and EP are removed from the accelerating section, the loading process is over. Test sample decelerationis performed by cellular polystyrene damper 12, forced through the tapered bush 14 (with the given force). Tolerable chamber charge density is $200 \mathrm{~kg} / \mathrm{m}^{3}$, initial loading force is $250 \mathrm{t}$. (The test sample and piston mass was 50 and $40 \mathrm{~kg}$ respectively).

\section{4.- Impact test stands for generating intence mechanical pulses.}

For testing large-scale test samples there has been developed and used a series of impact test stands, in which impulces forces up to several hundreds of tonnes and duration up to $10^{-2} \mathrm{~s}$ are generated by means of explosion chambers.

These test stands as compared to the above mentioned posses considerably larger store of gas and their accelerating and decelerating 
sections are longer. The throttling plugs with large level of throttling and opening diaphragms are used in these stands as shock-wave attenuator.

One of the most simple test stands from the point of view of its constructions and fabrication, allowing to test structures having up to $400 \mathrm{~mm}$ dimensions is shown in Fig. 4 .

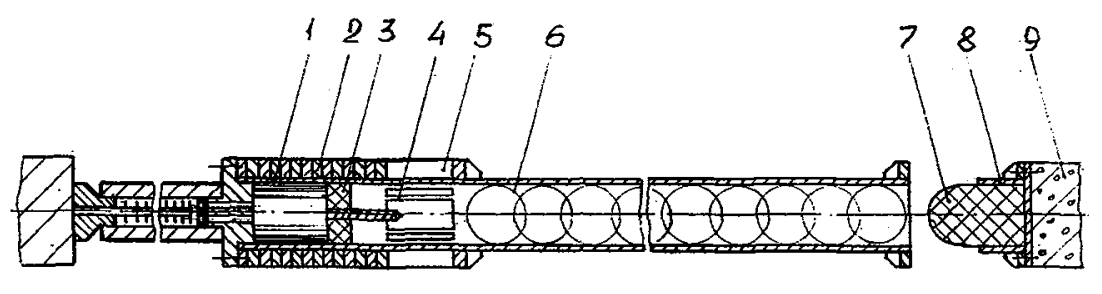

Fig. 4

The operating chamber volume is $6 \cdot 10^{-2} \mathrm{~m}^{3}$, tolerable charge density $85 \mathrm{~kg} / \mathrm{m}^{3}$, that provides the loading force of 1100 tonne. A part of the tube, used as an accelerating section 1 is strengthened by a set of sheet steel rings 2. Pressure release section $4(0.5 \mathrm{~m}$ length) has 6 rectangular slots. That part of the tube, where test sample deceleration takes place, is filled with polyethylene chips 6 . Foam piastic damper 7 , rested against a massive concrete recoiler 9 is mounted at the end of the decelerating section. Such decelerating system provides gradual deceleration of the test sample of $100 \mathrm{~kg}$ mass, accelerated to $300 \mathrm{~m} / \mathrm{s}$ velocity.

The devices, described in this paper, illustrate only some examples of the operating test stands. Besides, on similar principles there have been developed devices, which made it possible to carry out tests on alternations of stress. Experimental experience gained in these studies, demonstrated extensive application of these devices in different fields of science and engineering. These test stands are less expensive as compared to the corresponding impact test devices with similar parameters. 
1. Новиков С.А. Синицын В.А., Погорелов А.П. Fасчет в:зыгного нагружающего уетюйства длл создания импульса давления заданных параметров. ФГВ, 1980, Né, а.111-113.

2. Крысанов П.А. Новиков С.А. и др. Исоледование динамической ожима-

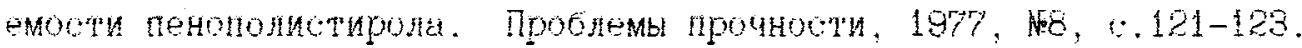

3. Крысанов 0.А., Новиков С.А. 06 ударном жатии пористых материалов. ПMTT, 1988, : $6.57-61$.

4. Абакумов А.И. Квасков Г.А, Новиков С.А. и др. Исоледование упругопластического деформирования цилиндрических оболочек при осевом нагружечии. ПитФ, 1988, $163,0.150-153$.

5. Новиков С.А. Петров В.А., Багрянов В.В. Уотановка взрывного типа для создания инерционных перегрузок. Проблемы прочности, 1982, Ке, c. $97-100$.

6. Новиков С.А., Петров В.А.,Сушков В.А. Хворостин В.Н. Установки взрывного типа для механических испытаний. ФГВ, 1989, 24, т. „5, C.14?-151

7. Большаков А.П., Новиков С.А., Синицын В.А. Исоледование динамических диаграмм одноосного растлженил и сжатия меди и сплава АмгБ. Проблемы прочности, 1979 , 1010, с.87-88.

8. Еременко А.С., Новиков С.А., Синицын В.А. Корреляция релаксационных и әнергетически характеристик разрушения полимеров при высоких скоростях нагружения. ДАН СССР, 1986, т.286, 166, с.1320-1323.

9. Большаков А.П., Новиков С.А., Синицын В.А. Прочность конструкционных материалов при динамических нагрувках (обзор). Вопросы атомной науки и техники, сер. вып. $1,6.23-46$.

10. Новиков С.А., Синицын В.А. , Цой П.А. Варывные уотройотва для механических испытаний материалов в экспериментах на импульных реакторах. Бопросы атомной науки и техники, сер. ИРПКС, 1986, вып 1, с.26-31.

11. Батрянов F?, Квакков Г.А., Новиков С.А., Смирнов И.Г. Методы внутриper сто ных испытаний конструкционных материалов в условиях двухосного динамичекого растьжения пои скоростах деформации $10^{2}-10^{4} \mathrm{c}^{-1}$. Бопросы атомной науки и техники, єер.ИРТКС, 1988 , вып.2, с.44-49.

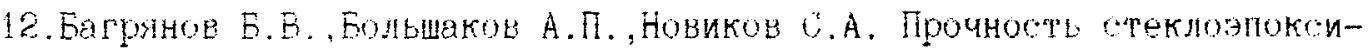
да при импуиьном нейтюнном облучении. Бопросы атомной науки и техники, Cер.ИFПКС, 1987, вып. 1, с.57-61. 